\title{
THE RENAL FACTOR IN ARTERIAL HYPERTENSION WITH COARCTATION OF THE AORTA ${ }^{1}$
}

\author{
By DAVID A. RYTAND \\ (From the Department of Medicine, Stanford University School of Medicine, San Francisco)
}

(Received for publication January 31, 1938)

Consideration of the hydrodynamics in coarctation of the aorta indicates that the arterial hypertension which is a feature of that disease is not to be explained upon the grounds of mechanical obstruction to blood flow per se. Such consideration has led to experiments which show that this variety of hypertension is owing to interference with renal blood supply.

Pathological physiology of coarctation of the aorta. In this condition, arterial pressure is practically always high in the arms, while it is usually low or normal (occasionally even high) in the legs (1). The hypertension in the upper part of the body is often attributed to the mechanical obstruction of the stenotic aortic isthmus to blood flow, but as Lewis (2) pointed out, the total cross section area of the collateral bed is at least equal to that of the normal aorta. However, the collateral vessels are long and tortuous and may easily account for the reduced pressure in the lower body as compared with the upper. Although the resistance of the collateral bed explains the difference between arm and leg pressure, it is not an explanation of the absolute pressure levels; were mechanical obstruction the only factor, one would always expect to find low pressure in the legs and less increase of pressure in the arms than actually occurs.

If the increased arterial pressure in the arms were a result of redistribution of blood such as occurred in the experiments of Barcroft and Samaan (3), then the cardiac output and flow of blood through the upper part of the body should be increased; this, however, has not been found $(2,4,5,6,7)$. Failure to demonstrate abnormally high rates of flow can mean only that peripheral resistance is increased in all the small vessels of the upper part of the body; the increased resistance in this region requires just as much explanation as does the generalized in-

1 This work was aided by a grant from the Rockefeller Foundation. creased resistance in any other variety of hypertension.

The presence of an increased resistance in the upper part of the body in coarctation of the aorta may perhaps be made clearer by a mathematical demonstration, using the well-known formula

$$
\text { Resistance }=\frac{\text { Pressure }}{\text { Flow }} \text {. }
$$

With pressure in $\mathrm{mm} . \mathrm{Hg}$ and flow in liters per minute, resistance may be expressed in arbitrary units with less confusion than when dynes are introduced (8).

When the regional fractionation of the cardiac output of a normal man weighing $70 \mathrm{kgm}$. and with a blood pressure of $125 / 80 \mathrm{~mm}$. $\mathrm{Hg}$ is calculated from the data of Levy and Blalock (9) for the $d o g$, and with mean pressure equal to diastolic pressure plus 43 per cent of pulse pressure (10), the representative results noted in Table I are obtained.

TABLE I

Calculated (approximate) regional blood flow and resistance for normal man

\begin{tabular}{|c|c|c|}
\hline Region & Blood flow & $\begin{array}{l}\text { Resistance in } \\
\text { arbitrary units }\end{array}$ \\
\hline & $\begin{array}{l}\text { liters per } \\
\text { minute }\end{array}$ & $\left(\frac{100 \mathrm{~mm} . \mathrm{H}_{\mathrm{g}}}{\text { liters per minule }}\right)$ \\
\hline 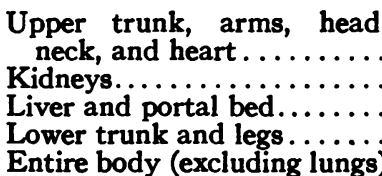 & $\begin{array}{l}2.00 \\
1.00 \\
1.50 \\
0.65 \\
5.15\end{array}$ & $\begin{aligned} 50 & (A) \\
100 & (B) \\
67 & (C) \\
154 & (D) \\
19 & (E)^{*}\end{aligned}$ \\
\hline
\end{tabular}

* The resistance for the entire body $(E)$ may also be calculated from $A, B, C$, and $D$ by the formula $\frac{1}{E}=\frac{1}{A}+\frac{1}{B}+\frac{1}{C}+\frac{1}{D}$, for calculating the total resistance offered by several resistances in parallel.

If now we consider a patient with coarctation of the aorta whose cardiac output is normal (6, 7 ), whose regional blood flow is normal or very nearly so $(2,4,5,11)$, and whose blood pressure is $195 / 100 \mathrm{~mm}$. $\mathrm{Hg}$ in the arms and $80 / 60 \mathrm{~mm}$. 


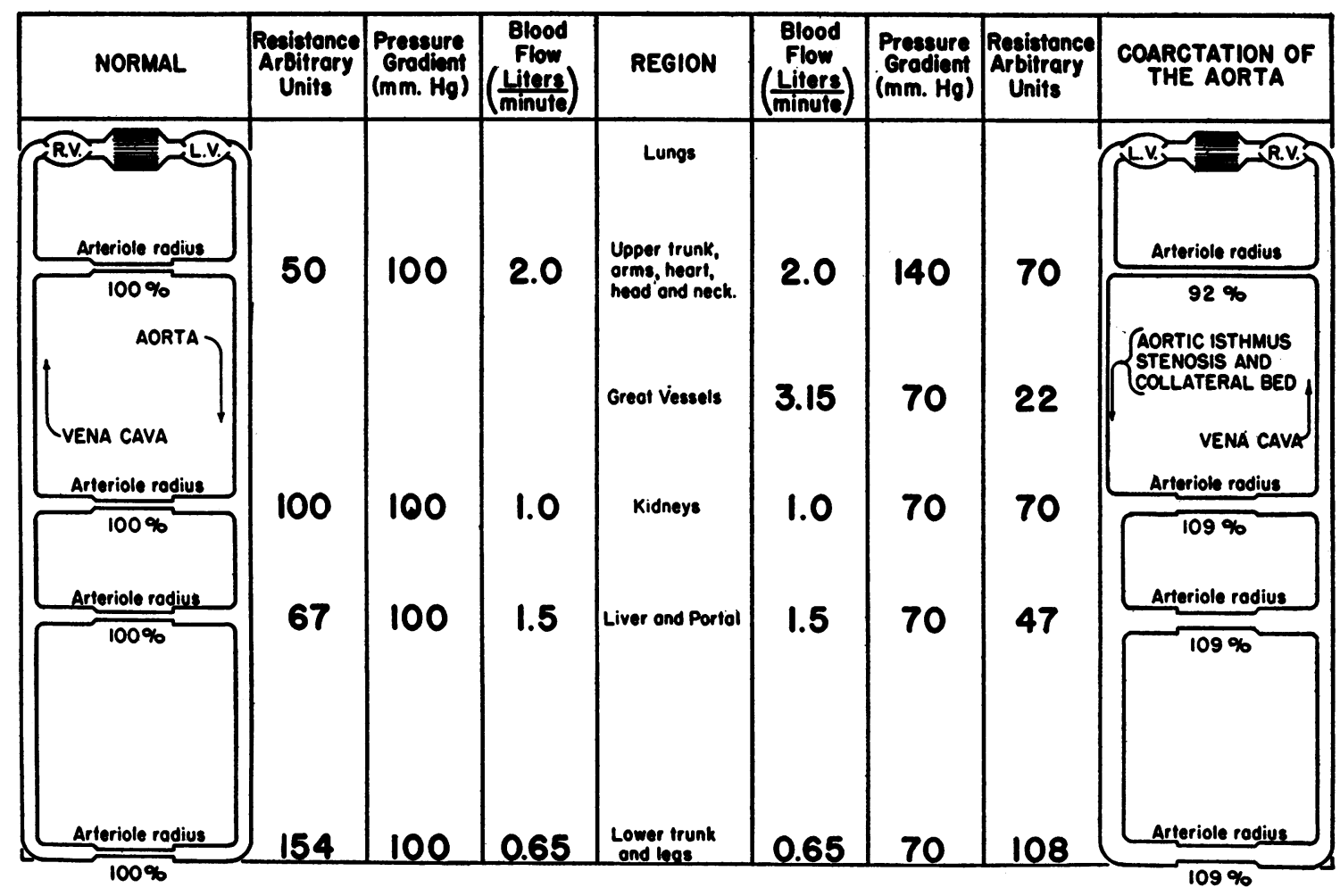

Fig. 1. Regional Resistance, Blood Flow, Arterial Pressure and Relative Arteriolar Radius in a Normal Subject (Blood Pressure 125/80 m m. Hg) and in a Subject with Coarctation of the Aorta (Blood Pressure, Arms 195/100, Legs 80/60 M M. Hg)

Note. The combined caliber of aortic isthmus stenosis and collateral bed approximates that of the normal aorta. Its width is narrow in the diagram to indicate the resistance due to length and tortuosity.

$\mathrm{Hg}$ in the legs, we may make the following calculations. Since the mean pressure in the lower aorta is approximately $70 \mathrm{~mm}$. $\mathrm{Hg}$ and that above the stenosis of the isthmus is $140 \mathrm{~mm}$. $\mathrm{Hg}$, the resistance of the stenosis and collateral bed is represented by the pressure gradient $(140-70$ $=70 \mathrm{~mm}$. $\mathrm{Hg}$ ) divided by the blood flow which they carry (abdominal viscera, lower trunk, and legs, or, 3.15 liters per minute), or 22 arbitrary units. As the tissues just mentioned are perfused with a normal volume flow per minute $(2,11)$ at a reduced pressure head, the resistance in this region must be decreased by 30 per cent. If the resistance had not decreased and the pressure had fallen from $125 / 80$ to $80 / 60 \mathrm{~mm}$. $\mathrm{Hg}$, then the flow would have been 30 per cent less than the observed level. But in the upper trunk, arms, head, neck, and heart, 2.0 liters per minute still circulate under a pressure head of $140 \mathrm{~mm}$. $\mathrm{Hg}$, so that here the resistance must have increased from 50 to 70 arbitrary units or by 40 per cent. Figure 1 shows these changes, the fundamental significance of which is not altered by the probable inaccuracies in the calculated absolute values of the regional flows.

Since the resistance varies inversely with the fourth power of (arteriolar) radius, a decrease in radius of 10 per cent increases the resistance 50 per cent, and a decrease in radius of 15 per cent doubles the resistance. In coarctation of the aorta the resistance of the upper part of the body usually varies between 150 and 200 per cent of that in the lower part, so the radius of an arteriole from the arm would be only 15 per cent smaller than that of one from the leg. Bearing in mind the difficulties inherent in measuring fixed arterioles, one could have predicted that no significant difference in caliber of such vessels from arm and leg would be observed, a theoretical conclusion compatible with actual measurement (12). In 
this particular series, the calculated expected difference was only 10 per cent.

It seemed that the cause of the increased resistance and pressure in the upper body in coarctation of the aorta might be the same as that of the generalized changes in the Goldblatt dog (13), for in each case renal tissue is distal to a partially occluded artery. It has been shown that the kidney is apparently unique in the pathogenesis of hypertension when an organ's artery is partially occluded (13). Bell's suggestion that the hypertension in coarctation of the aorta is fundamentally similar to that in the dog with a partially occluded renal artery was rejected by Goldblatt $(14) ;^{2}$ the problem has now been studied experimentally.

Hypertension as evidenced by left ventricular cardiac hypertrophy was produced in 11 rats by partial occlusion of the aorta between the right (proximal) and left (distal) renal arteries. With similar occlusion hypertension did not occur in 25 other rats when the left kidney was removed simultaneously. In other words, partial occlusion of the aorta at the same site in two groups of rats produced hypertension only in that group with renal tissue distal to the occlusion, even though the blood flow was hindered by the same mechanical obstruction owing to stenosis and a collateral bed in both groups. Hypertension was also produced in 12 rats by partial occlusion of the aorta just above both kidneys, a site more nearly analogous to that of the obstruction in coarctation of the aorta.

\section{METHODS}

The results in this paper were obtained from over 175 experiments on albino rats, each sacrificed 20 days after operation. The general conditions and methods used in this laboratory have been reported previously; the diet contained 10 per cent casein and 19 per cent total protein (15).

Operative technique. The operative technique is a modification of Collins' method (16). No attempt at asepsis is made. The rat is anesthetized with ether and a long midline abdominal incision made. If the left renal artery is to be tied, it is dissected free, usually be-

\footnotetext{
2 Goldblatt and Kahn (J. A. M. A., 1938, 110, 49, footnote $1(\mathrm{~h})$, and personal communication) find in the dog that partial occlusion of the aorta below both renal arteries is not followed by hypertension; similar occlusion immediately above both renal arteries produces hypertension.
}

tween the kidney and the suprarenal vein; occasionally it is best freed between the latter and the aorta. A wire $0.4 \mathrm{~mm}$. in diameter is placed parallel to the exposed artery, and a silk thread passed beneath both wire and artery. The thread is then tied, the ligature of course including wire and artery. The wire may then be gently withdrawn, the ligature remaining; the abdominal incision is closed in the usual manner. If the aorta is to be tied, it may be freed at the desired site (between the renal arteries or just above them) and tied together with a wire $0.9 \mathrm{~mm}$. in diameter. Occasionally the thoracic duct is ruptured, but heals spontaneously. The sizes of the wires given above are satisfactory for rats of about 100 to 200 grams, but practice is necessary to learn the appropriate force with which to tie the ligature. In a successful experiment, the kidney blanches on tying, then undergoes reactive hyperemia immediately on removal of the wire.

Organ weights. In rats sacrificed 20 days after operation, the heart and kidneys were weighed on torsion balances and compared with the predicted weights of those organs in normal rats of the same weight and sex. The predictions were based on the following formulae derived by $\mathrm{Dr}$. T. Addis from data collected in this laboratory on over 1500 rats :

$$
\begin{array}{ll}
\text { Male heart: } & \mathrm{HW}=12.6 \mathrm{BW}^{0.75}+8 . \\
\text { Female heart: } & \mathrm{HW}=12.56 \mathrm{BW}^{0.75}+1.5 . \\
\text { Male kidney (single) : } & \mathrm{KW}=15.0 \mathrm{BW}^{0.712}+10.3 .
\end{array}
$$

In these formulae, more accurate than the similar formulae based upon surface area $\left(\mathrm{kBW}^{0.07}\right)$, organ weights are in milligrams, body weights in grams. Statistical studies show that the normal variability of heart weight is so small that its coefficient of variation at a given range of body weight of 10 grams is only 3.7 per cent. This means that an observed deviation (from the weight predicted by the equations) of \pm 10 per cent occurs only once in 143 normal rats; a deviation of \pm 15 per cent occurs once in every 15,770 rats; any individual deviation of \pm 12 per cent or more is "almost certainly" significant. Kidney weight is normally more variable, its coefficient of variation being 9.8 per cent. Therefore, an observed deviation in kidney weight of \pm 10 per cent occurs as often as once in every 3 rats, \pm 15 per cent once in $8, \pm 25$ per cent once in every 143 ; in order to be statistically significant, a single observed kidney weight must deviate \pm 28 per cent from the prediction. Averages of groups of hearts or kidneys are much less variable. The rats in the present experiment were under exactly the same conditions as were those from which the data were obtained for the formulae (same diet, constant temperature, etc.), and the formulae are believed to apply only under constant conditions.

The degree of cardiac hypertrophy was used as an index of the effect of the procedures on the arterial pressure. In the absence of anemia or metabolic disease, and when an increased $L / R$ ratio is present, the increase in heart weight seems to be a better criterion of the average daily level of arterial pressure than readings obtained 
under anesthesia by methods which are, in our hands, not satisfactory. Anemia was excluded by the fact that hematocrit values in a group of hypertensive rats averaged 93 per cent of those of controls. The hearts from 23 nonhypertensive and 14 unselected hypertensive rats were fixed, and the right and left ventricles separated and weighed. The $L / R$ ratio, corrected as previously described (15), was 21 per cent greater in the hypertensive group, a difference five times its probable error and therefore statistically significant.

In order to translate the observed cardiac hypertrophy into blood pressure levels, it may be noted that Chanutin and Barksdale (17) have shown that in the rat a hypertrophy of 25 per cent occurs with a chronic hypertension of 160 to $170 \mathrm{~mm} . \mathrm{Hg}, 50$ per cent with $180 \mathrm{~mm}$. $\mathrm{Hg}$ or over. Since the present experiments were of shorter duration, the existing pressure levels were probably higher at any given degree of cardiac hypertrophy.

\section{RESULTS}

Detailed protocols are given in the Tables; a summary is presented in Figure 2. The experiments are best discussed in six divisions.

\begin{tabular}{|c|c|c|c|c|c|}
\hline \multicolumn{2}{|c|}{ EXPERIMENT } & \multicolumn{4}{|c|}{ ORGAN WEIGHTS, } \\
\hline \multirow{3}{*}{. } & \multicolumn{5}{|c|}{ \% DEVIATION FROM NORMAL } \\
\hline & \multirow{2}{*}{ 占 } & \multirow{2}{*}{ HEART } & \multicolumn{2}{|c|}{ KIDNEY } & \multirow{2}{*}{$\begin{array}{l}\text { MUMBER } \\
\text { OF RATS }\end{array}$} \\
\hline & & & RIGHT & LEFT & \\
\hline A & & $+2 \%$ & $+38 \%$ & $-100 \%$ & 14 \\
\hline$A$ & & $\pm 0 x$ & $+39 \%$ & $-75 \%$ & 3 \\
\hline 0 & & $-2 \%$ & $+34 \%$ & $-100 \%$ & 25 \\
\hline 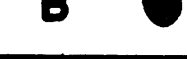 & & $\pm 0 \%$ & $+28 \%$ & $-76 \%$ & 1 \\
\hline C & & $+28 \%$ & $+39 \%$ & $-65 \%$ & 9 \\
\hline D & & $+26 \%$ & $+37 \%$ & $-49 \%$ & 7 \\
\hline $\mathbf{E}$ & & $+29 \%$ & $-100 \%$ & $+16 \%$ & 4 \\
\hline$F$ & & $+20 \%$ & $-1 \%$ & $-4 \%$ & 12 \\
\hline
\end{tabular}

Fig. 2. Summary of Results Obtained in Rats Sacrificed 20 Days after the Operative Procedure INDICATED BY THE DIAGRAMS

A. Partial occlusion of the left renal artery, with left nephrectomy. This combined procedure was of course a control. These 14 rats were not expected to have hypertension and in fact did not. The average heart weight was +2 per cent of that predicted, while the right kidney presented the usual degree of compensatory hypertrophy ( +38 per cent). In addition, three more rats (operated upon as in Experiment C) are included because in them the ligature was too tight; as a result the left kidney became necrotic (autonephrectomy).

B. Partial occlusion of the aorta between the renal arteries, with left (distal) nephrectomy. If the hypertension of coarctation of the aorta is to be explicable upon the basis of mechanical obstruction, these rats should have hypertension. On the contrary, the average heart weight of 25 rats was 2 per cent less than predicted, and not a single rat had cardiac hypertrophy. A possible objection is that the ligatures may have been too loose; the answers are $(a)$ that these rats were operated upon alternately with those of Experiment $\mathrm{D}$, in which hypertension occurred in onethird of the rats, and $(b)$ in 6 rats of this series the aorta became completely obstructed (pulsations entirely absent) by intimal proliferation (Figure 3 shows the collateral circulation in such a rat). To these 25 rats may be added 1 from Experiment D in which the left kidney was completely necrotic.

C. Partial occlusion of the left renal artery. This series was designed to demonstrate that a modification of the Goldblatt technique would produce hypertension in the rat. That it does in fact do so is shown by the cardiac hypertrophy in 9 animals, as much as +54 per cent and averaging +28 per cent. In these animals the left kidney atrophied ( -65 per cent) with little or no necrosis.

D. Partial occlusion of the aorta between the renal arteries. In this experiment 7 rats had hypertension as evidenced by cardiac hypertrophy averaging +26 per cent (as high as +37 per cent), and in these the left (distal) kidney atrophied (- 49 per cent) just as in Experiment C.

This is a series of rats operated upon alternately with those of Experiment B and at exactly the same site; hypertension occurred only when there was renal tissue distal to the obstruction, and only when this tissue was atrophic but not necrotic.

E. Partial occlusion of the aorta between the renal arteries, with right (proximal) nephrectomy. So far in these studies hypertension has been uni- 


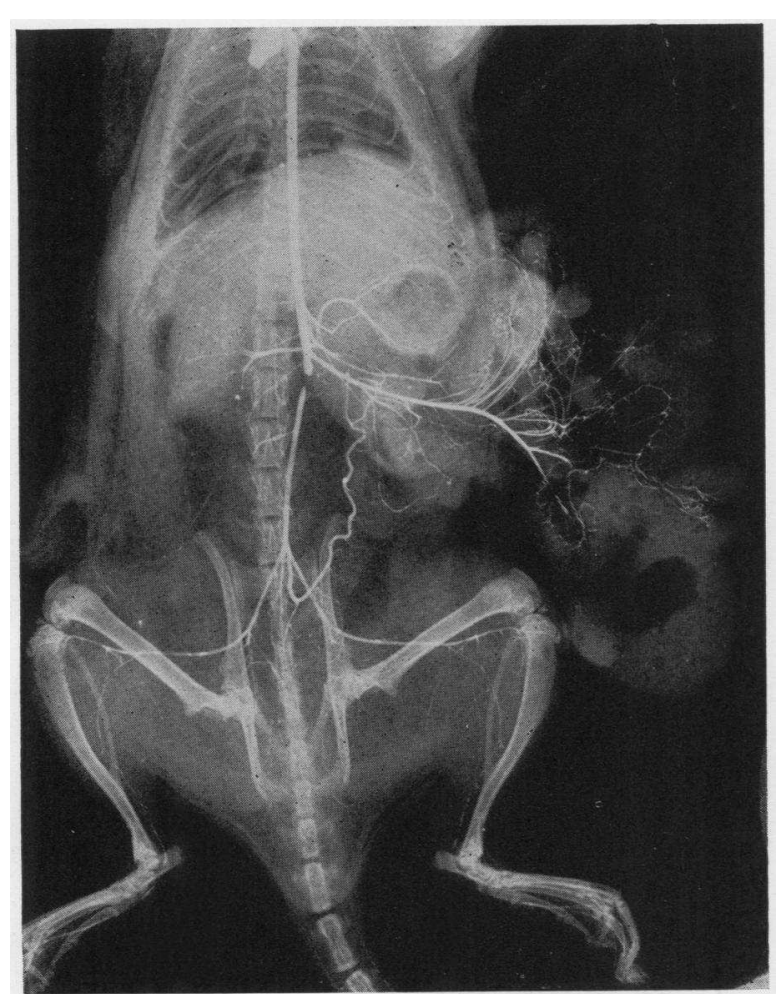

Fig. 3. Roentgenogram after Intracardiac InjeCtion of Opaque Material Showing the Collateral Circulation in a Nonhypertensive Rat (Left Nephrectomy, Complete Occlusion of Aorta Distal to Right Kidney)

formly associated with unilateral renal atrophy. In this series there were 4 rats with cardiac hypertrophy up to +55 per cent (average +29 per cent), and in these there was actually hypertrophy $(+16$ per cent $)$ of the remaining kidney distal to the partial occlusion. In 3 of these the aorta was completely occluded.

F. Partial occlusion of the aorta above both kidneys. In this series the situation is unlike the previous ones or the Goldblatt dog but is similar to that existing spontaneously in coarctation of the aorta. Here, as in coarctation, the aorta is partially occluded above both kidneys and there is (as in Experiments $B, D$, and $E$ ) a collateral circulation supplying tissues distal to the obstruction. In 12 rats in this series the cardiac hypertrophy averaged +20 per cent (as high as +38 per cent) and the kidneys were entirely normal (within 4 per cent of the prediction). The aortic obstruction was complete in 1 rat and very nearly so in another.
In Experiment $C$ there were 6 rats and in D 16 rats in which neither cardiac hypertrophy nor left renal atrophy occcurred; presumably, the ligatures in these instances were too loose to alter hydrodynamics appreciably. Likewise, there were 23 rats in Experiment $\mathrm{E}$ and 7 in $\mathrm{F}$ without cardiac hypertrophy; the same explanation probably holds. Such animals are therefore omitted from consideration since there is no evidence, direct or indirect, of aortic or renal artery stenosis. Since they serve as controls, their pertinent data are included in Tables IV to VII, but averaged separately. In another 51 rats in which the ligature was too tight, necrosis of tissues beyond it occurred in a few days; when this occurred with the tie on the left renal artery the kidney became necrotic, with the aorta tied the animal died.

The concentration of urea in the blood is normal in coarctation. In the rats of Experiment $\mathrm{F}$ it varied from 30.6 to $38.9 \mathrm{mgm}$. per cent, well within normal limits. In those experiments in which unilateral nephrectomy was done, the blood

TABLE II

Experiment A. Partial occlusion of the left renal artery with left nephrectomy

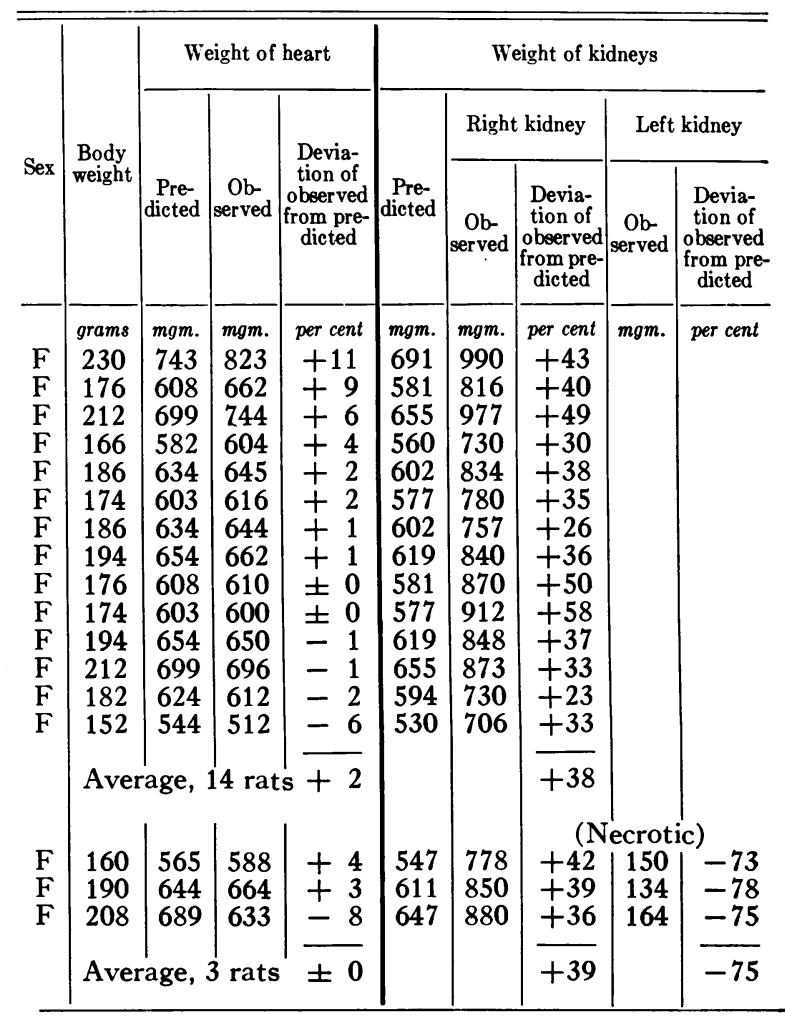


TABLE III

Experiment B. Partial occlusion of the aorta between the renal arteries, with left (distal) nephrectomy

\begin{tabular}{|c|c|c|c|c|c|c|c|c|c|}
\hline \multirow{3}{*}{ Sex } & \multirow{3}{*}{$\begin{array}{c}\text { Body } \\
\text { weight }\end{array}$} & \multicolumn{3}{|c|}{ Weight of heart } & \multicolumn{5}{|c|}{ Weight of kidneys } \\
\hline & & \multirow[b]{2}{*}{$\begin{array}{r}\text { Pre- } \\
\text { dicted }\end{array}$} & \multirow[b]{2}{*}{$\begin{array}{c}\text { Ob- } \\
\text { served }\end{array}$} & \multirow{2}{*}{$\begin{array}{c}\text { Devia- } \\
\text { tion of } \\
\text { observed } \\
\text { from pre- } \\
\text { dicted }\end{array}$} & \multirow[b]{2}{*}{\begin{tabular}{c|} 
Pre- \\
dicted
\end{tabular}} & \multicolumn{2}{|c|}{ Right kidney } & \multicolumn{2}{|c|}{ Left kidney } \\
\hline & & & & & & \begin{tabular}{|c|} 
Ob- \\
served
\end{tabular} & $\begin{array}{c}\text { Devia- } \\
\text { tion of } \\
\text { observed } \\
\text { from pre- } \\
\text { dicted }\end{array}$ & $\begin{array}{l}\text { Ob- } \\
\text { served }\end{array}$ & $\begin{array}{c}\text { Devia- } \\
\text { tion of } \\
\text { observed } \\
\text { from pr- } \\
\text { dicted }\end{array}$ \\
\hline & grams & mgm. & mgm. & per cent & mgm. & mgm. & per cent & mgm. & per cent \\
\hline $\mathrm{M}$ & 166 & 590 & 628 & +6 & 596 & 744 & +25 & & \\
\hline M & 170 & 600 & 630 & +5 & 606 & 954 & +57 & & \\
\hline $\mathrm{F}$ & $143^{*}$ & 521 & 545 & +5 & 509 & 732 & +44 & & \\
\hline $\mathrm{F}$ & 146 & 529 & 552 & +4 & 516 & 672 & +30 & & \\
\hline M & 164 & 585 & 608 & +4 & 591 & 834 & +41 & & \\
\hline M & 180 & 626 & 646 & +3 & 631 & 842 & +33 & & \\
\hline M & 153 & 556 & 572 & +3 & 563 & 786 & +40 & & \\
\hline $\mathbf{M}$ & 184 & 637 & 645 & +1 & 641 & 908 & +41 & & \\
\hline M & $164^{*}$ & 585 & 582 & \pm 0 & 591 & 872 & +48 & & \\
\hline M & 138 & 515 & 517 & \pm 0 & 523 & 694 & +33 & & \\
\hline $\mathrm{M}$ & 184 & 637 & 636 & \pm 0 & 641 & 980 & +53 & & \\
\hline M & 184 & 637 & 634 & \pm 0 & 641 & 870 & +36 & & \\
\hline $\mathbf{M}$ & 164 & 585 & 580 & -1 & 591 & 848 & +43 & & \\
\hline M & 140 & 521 & 514 & -1 & 528 & 660 & +25 & & \\
\hline M & $170^{*}$ & 600 & 587 & -2 & 606 & 846 & +40 & & \\
\hline M & 188 & 648 & 632 & -2 & 651 & 894 & +37 & & \\
\hline$F$ & 108 & 422 & 412 & -2 & 425 & 537 & +26 & & \\
\hline $\mathrm{M}$ & $290^{*}$ & 894 & 860 & -4 & 885 & 1020 & +15 & & \\
\hline $\mathrm{F}$ & 138 & 507 & 486 & -4 & 498 & 592 & +19 & & \\
\hline M & $210^{*}$ & 704 & 672 & -5 & 704 & 952 & +35 & & \\
\hline $\mathrm{F}$ & 152 & 544 & 510 & -8 & 530 & 764 & +44 & & \\
\hline $\mathrm{F}$ & 122 & 462 & 422 & -9 & 459 & 580 & +26 & & \\
\hline M & 154 & 558 & 506 & -9 & 565 & 680 & +20 & & \\
\hline $\mathrm{F}$ & 122 & 462 & 414 & -10 & 459 & 522 & +14 & & \\
\hline \multirow[t]{2}{*}{ M } & $122^{*}$ & 470 & 415 & -12 & 480 & 604 & +26 & & \\
\hline & \multicolumn{4}{|c|}{ Average, 25 rats -2} & & & +34 & & \\
\hline & & & & & & & $(\mathrm{N}$ & & \\
\hline M & 174 & 610 & 612 & \pm 0 & 616 & 786 & +28 & 150 & -76 \\
\hline
\end{tabular}

* Represents complete occlusion of aorta.

urea concentrations of the hypertensive rats were 40.3 to $50.0 \mathrm{mgm}$. per cent, the usual values for nonhypertensive rats 20 days after unilateral nephrectomy.

Proteinuria is not ordinarily present in coarctation of the aorta. Nor was it found in these hypertensive rats (average $1.3 \mathrm{mgm}$. per day (females), as compared to the controls of $1.1 \mathrm{mgm}$. per day).

\section{DISCUSSION}

Partial occlusion of either the aorta or one renal artery in rats is followed by cardiac hypertrophy only when there is living renal tissue beyond the occlusion: the left ventricle undergoes hypertrophy relative to the right, and other causes of cardiac hypertrophy are absent; under these conditions we feel justified in stating that such rats are hypertensive. Proteinuria does not occur and renal function is normal as judged by blood urea concentration, just as in coarctation of the aorta. The nutritional state of the animals is not impaired. On the other hand, when renal tissue is absent distal to the occlusion, hypertension does not occur even though blood must flow in the presence of the same degree of mechanical obstruction.

Just as the pressure head beyond the stenosis of the aortic isthmus is lower than that proximal to the stenosis, so Blalock and Levy (18) have shown that the pressure beyond a partial occlusion of the renal artery is lower (by 50 per cent) than the general arterial pressure. It is not known whether the important hypertensive factor in interference with the renal blood supply is local hypotension, reduced pulse pressure, or reduced blood flow.

The kidney beyond a partially occluded renal artery has often been spoken of as "ischemic." On the other hand, its function is said to be normal. If Van Slyke et al. (19) are correct in correlating renal function with blood flow, one or

TABLE IV

Experiment C. Partial occlusion of the left renal artery

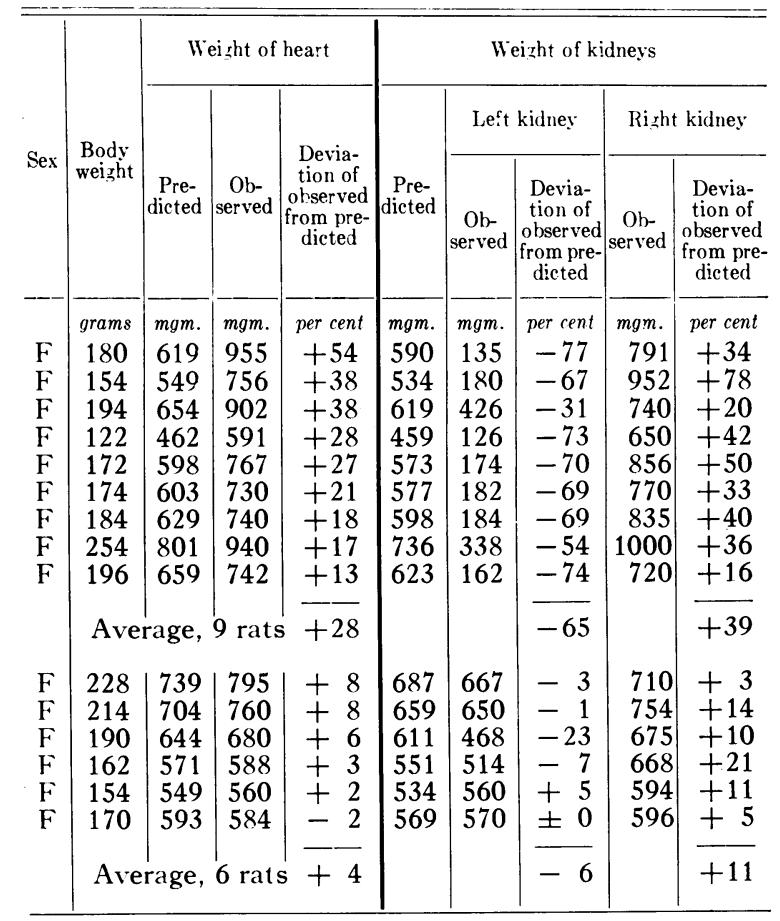


TABLE V

Experiment D. Partial occlusion of the aorta between the renal arteries

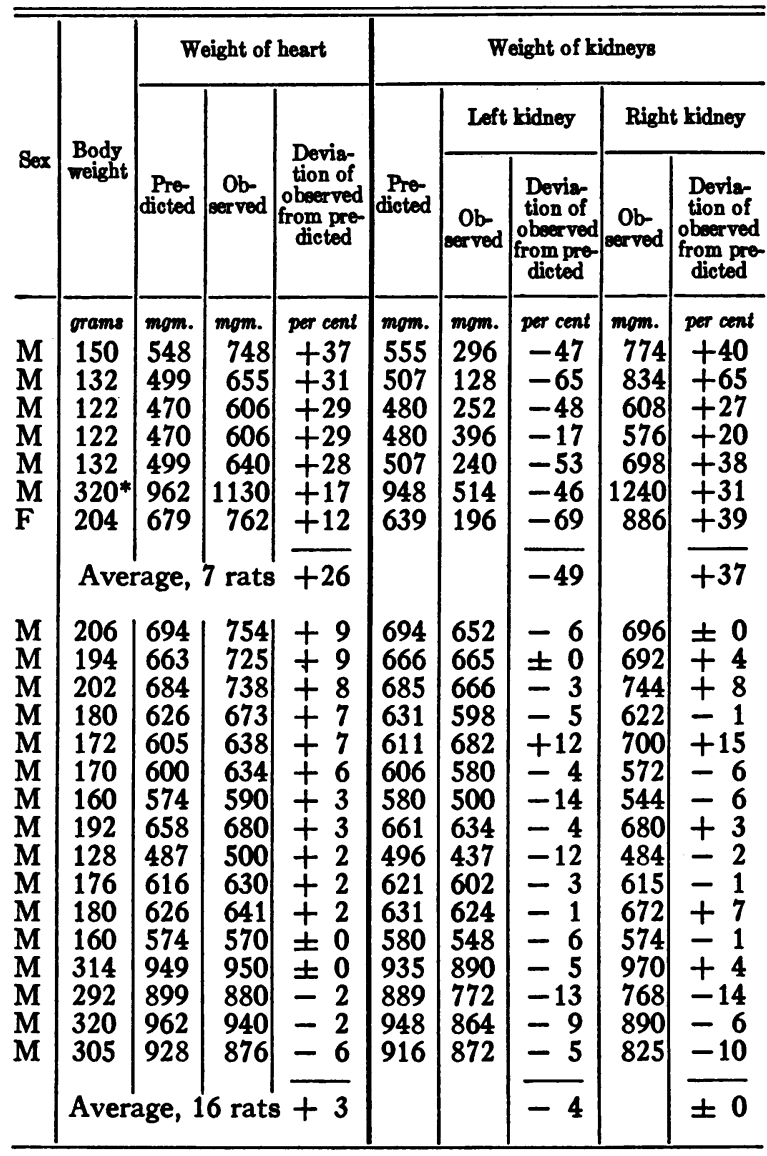

* Represents complete occlusion of aorta.

the other of the above statements is incorrect. Actually, neither renal blood flow nor renal function by rigid tests has ever been studied adequately under these conditions; Mason, Evers, and Blalock (20) have failed to demonstrate ischemia, using $\mathrm{A}-\mathrm{V}$ oxygen differences. In dogs with ureteral obstruction, renal blood flow is uniformly reduced but hypertension does not always occur (21), while in still another variety of hypertension (after subtotal nephrectomy) rats have normal renal blood flows (22). It seems probable that in the Goldblatt dog, renal flow is near the lower limit of normal as long as hypertension is present.

Perhaps only the kidney, of all the tissues, has the power to raise general blood pressure when its blood supply suffers interference. Hartmann, $\emptyset$ rskov, and Rein (23) showed that, in spite of pressor reflexes and adrenalin, renal blood flow remains constant although flow through the leg undergoes simultaneous wide fluctuations; they suggest that the kidneys may regulate the circulation in the same sense as does the carotid sinus. It is not clear whether this supposed regulatory action is explicable wholly on some metabolic process specific to renal tissue, or whether the peculiarities of the arrangement (24) of the renal blood vessel are also involved. The present experiments on rats do not show whether partial occlusion of the aorta proximal to the celiac axis can cause hypertension of greater degree than distal occlusion, nor has it been proved that hypertension does not follow narrowing of the splanchnic arteries.

Hypertension may be produced by partial occlusion of the blood supply of a completely dener-

TABLE VI

Experiment $E$. Partial occlusion of the aorta between the renal arteries, with right (proximal) nephrectomy

\begin{tabular}{|c|c|c|c|c|c|c|c|}
\hline \multirow[b]{2}{*}{ Sex } & \multirow{2}{*}{$\begin{array}{l}\text { Body } \\
\text { weight }\end{array}$} & \multicolumn{3}{|c|}{ Weight of heart } & \multicolumn{3}{|c|}{ Weight of left kidney } \\
\hline & & $\begin{array}{l}\text { Pro- } \\
\text { dicted }\end{array}$ & $\underset{\text { Ob-rved }}{\mathrm{Ob}}$ & $\begin{array}{l}\text { Deviation of } \\
\text { obeerved } \\
\text { from pro- } \\
\text { dioted }\end{array}$ & $\begin{array}{l}\text { Pro- } \\
\text { dicted }\end{array}$ & $\begin{array}{c}\text { Ob- } \\
\text { served }\end{array}$ & $\begin{array}{l}\text { Deviation o } \\
\text { obeerved } \\
\text { from pro- } \\
\text { dicted }\end{array}$ \\
\hline $\begin{array}{l}\mathbf{F} \\
\mathbf{M} \\
\mathbf{M} \\
\mathbf{F}\end{array}$ & $\begin{array}{l}\text { grams } \\
117^{*} \\
178 \\
114^{*} \\
119^{*}\end{array}$ & $\begin{array}{l}\text { mom. } \\
448 \\
621 \\
447 \\
454\end{array}$ & $\begin{array}{c}\text { mom. } \\
\mathbf{6 9 5} \\
\mathbf{7 6 4} \\
534 \\
537\end{array}$ & $\begin{array}{l}\text { per cont } \\
+55 \\
+23 \\
+20 \\
+18\end{array}$ & $\begin{array}{l}\text { mom. } \\
447 \\
626 \\
458 \\
452\end{array}$ & $\begin{array}{l}\text { mom. } \\
\mathbf{5 5 2} \\
\mathbf{7 3 8} \\
494 \\
\mathbf{5 2 6}\end{array}$ & $\begin{array}{c}\text { per cent } \\
+23 \\
+18 \\
+8 \\
+16\end{array}$ \\
\hline $\begin{array}{l}\mathbf{F} \\
\mathbf{M} \\
\mathbf{F} \\
\mathbf{M} \\
\mathbf{M} \\
\mathbf{F} \\
\mathbf{F} \\
\mathbf{M} \\
\mathbf{M} \\
\mathbf{M} \\
\mathbf{M} \\
\mathbf{M} \\
\mathbf{M} \\
\mathbf{M} \\
\mathbf{M} \\
\mathbf{M} \\
\mathbf{M} \\
\mathbf{M} \\
\mathbf{M} \\
\mathbf{M} \\
\mathbf{M} \\
\mathbf{M} \\
\mathbf{M}\end{array}$ & $\begin{array}{r}140 \\
166 \\
112 \\
116 \\
200 \\
126 \\
144 \\
136 \\
168 \\
177 \\
198 \\
150 \\
143 \\
168 \\
202 \\
190 \\
158 \\
93 \\
190 \\
196 \\
102 \\
134 \\
136\end{array}$ & $\begin{array}{l}\text { verag } \\
512 \\
590 \\
434 \\
453 \\
679 \\
474 \\
523 \\
510 \\
595 \\
618 \\
673 \\
548 \\
529 \\
595 \\
684 \\
653 \\
569 \\
385 \\
653 \\
668 \\
412 \\
504 \\
510\end{array}$ & $\begin{array}{l}4 \text { rat } \\
561 \\
642 \\
463 \\
482 \\
714 \\
500 \\
546 \\
530 \\
618 \\
640 \\
688 \\
554 \\
532 \\
596 \\
682 \\
644 \\
558 \\
378 \\
634 \\
643 \\
395 \\
478 \\
482\end{array}$ & $\begin{array}{l}+29 \\
+10 \\
+9 \\
+8 \\
+6 \\
+5 \\
+5 \\
+4 \\
+4 \\
+4 \\
+4 \\
+3 \\
+2 \\
+1 \\
+1 \\
\pm 0 \\
\pm 0 \\
=1 \\
=2 \\
=2 \\
-3 \\
-4 \\
=4 \\
=5 \\
-5\end{array}$ & $\begin{array}{l}502 \\
596 \\
435 \\
463 \\
680 \\
469 \\
511 \\
518 \\
601 \\
623 \\
675 \\
555 \\
536 \\
601 \\
685 \\
\mathbf{6 5 6} \\
\mathbf{5 7 5} \\
397 \\
656 \\
670 \\
423 \\
513 \\
\mathbf{5 1 8}\end{array}$ & $\begin{array}{l}615 \\
759 \\
546 \\
614 \\
813 \\
556 \\
612 \\
702 \\
702 \\
882 \\
908 \\
770 \\
690 \\
746 \\
850 \\
824 \\
763 \\
433 \\
815 \\
763 \\
494 \\
674 \\
694\end{array}$ & $\begin{array}{l}+16 \\
+22 \\
+27 \\
+25 \\
+33 \\
+20 \\
+18 \\
+20 \\
+36 \\
+17 \\
+42 \\
+35 \\
+39 \\
+29 \\
+24 \\
+24 \\
+26 \\
+33 \\
+9 \\
+24 \\
+14 \\
+17 \\
+31 \\
+34\end{array}$ \\
\hline & & 108 & & & & & +26 \\
\hline
\end{tabular}

* Represents complete occlusion of aorta. 
TABLE VII

Experiment F. Partial occlusion of the aorta above both kidneys

\begin{tabular}{|c|c|c|c|c|c|c|c|c|c|}
\hline \multirow{3}{*}{ Sex } & \multirow{3}{*}{$\begin{array}{l}\text { Body } \\
\text { weight }\end{array}$} & \multicolumn{3}{|c|}{ Weight of heart } & \multicolumn{5}{|c|}{ Weight of kidneys } \\
\hline & & \multirow[b]{2}{*}{$\begin{array}{c}\text { Pro- } \\
\text { dicted }\end{array}$} & \multirow[b]{2}{*}{ Ob- } & \multirow[b]{2}{*}{$\begin{array}{l}\text { Devia- } \\
\text { tion of } \\
\text { observed } \\
\text { from pre- } \\
\text { dicted }\end{array}$} & \multirow[b]{2}{*}{ Pre- } & \multicolumn{2}{|c|}{ Left kidney } & \multicolumn{2}{|c|}{ Right kidney } \\
\hline & & & & & & Ob- & $\begin{array}{c}\text { Devia- } \\
\text { tion of } \\
\text { obeerved } \\
\text { from pre- } \\
\text { dicted }\end{array}$ & Ob- & $\begin{array}{l}\text { Devia } \\
\text { tion of } \\
\text { obeerved } \\
\text { from pre } \\
\text { dicted }\end{array}$ \\
\hline $\begin{array}{l}\mathbf{M} \\
\mathbf{M} \\
\mathbf{M} \\
\mathbf{M} \\
\mathbf{M} \\
\mathbf{M} \\
\mathbf{M} \\
\mathbf{M} \\
\mathbf{M} \\
\mathbf{M} \\
\mathbf{M} \\
\mathbf{M}\end{array}$ & $\begin{array}{l}\text { grams } \\
130 \\
142 \\
112 \\
172 \\
122 \\
114 \\
158 \\
178^{*} \\
154 \\
162 \\
128 \\
160\end{array}$ & \begin{tabular}{|l} 
mom. \\
493 \\
526 \\
442 \\
606 \\
470 \\
447 \\
569 \\
621 \\
558 \\
579 \\
487 \\
574 \\
\end{tabular} & \begin{tabular}{|c|} 
mom. \\
680 \\
676 \\
546 \\
736 \\
568 \\
536 \\
666 \\
726 \\
640 \\
666 \\
562 \\
657
\end{tabular} & $\begin{array}{c}\text { per cent } \\
+38 \\
+28 \\
+23 \\
+21 \\
+21 \\
+20 \\
+17 \\
+17 \\
+15 \\
+15 \\
+15 \\
+14\end{array}$ & \begin{tabular}{|l|} 
mom. \\
502 \\
534 \\
452 \\
611 \\
480 \\
458 \\
575 \\
626 \\
565 \\
586 \\
496 \\
580
\end{tabular} & $\begin{array}{l}\text { mgm. } \\
502 \\
568 \\
412 \\
568 \\
475 \\
414 \\
604 \\
540 \\
535 \\
568 \\
474 \\
562\end{array}$ & $\begin{array}{c}\text { per cent } \\
\pm 0 \\
\pm 6 \\
-9 \\
-7 \\
-1 \\
-10 \\
+5 \\
-14 \\
-5 \\
-3 \\
-4 \\
-3\end{array}$ & \begin{tabular}{|l|} 
mom. \\
480 \\
667 \\
435 \\
544 \\
510 \\
445 \\
648 \\
556 \\
532 \\
570 \\
460 \\
546
\end{tabular} & $\begin{array}{l}\text { per cent } \\
-4 \\
+25 \\
-4 \\
-11 \\
+6 \\
=3 \\
+13 \\
-11 \\
-6 \\
-3 \\
-7 \\
-6\end{array}$ \\
\hline $\begin{array}{l}\mathbf{M} \\
\mathbf{M} \\
\mathbf{M} \\
\mathbf{M} \\
\mathbf{M} \\
\mathbf{M} \\
\mathbf{M}\end{array}$ & $\begin{array}{l}170 \\
178 \\
140 \\
175 \\
224 \\
100 \\
144\end{array}$ & $\begin{array}{l}600 \\
621 \\
521 \\
613 \\
738 \\
406 \\
532\end{array}$ & $\begin{array}{l}652 \\
670 \\
548 \\
638 \\
718 \\
390 \\
480\end{array}$ & $\begin{array}{l}+9 \\
+8 \\
+5 \\
+3 \\
-3 \\
-4 \\
-10\end{array}$ & $\begin{array}{l}606 \\
626 \\
528 \\
618 \\
737 \\
417 \\
539\end{array}$ & $\begin{array}{l}660 \\
552 \\
517 \\
588 \\
670 \\
340 \\
466\end{array}$ & $\begin{array}{r}-4 \\
+9 \\
-12 \\
-2 \\
-5 \\
-9 \\
-18 \\
-14\end{array}$ & \begin{tabular}{|l|}
660 \\
624 \\
527 \\
604 \\
693 \\
350 \\
474
\end{tabular} & $\begin{array}{r}-1 \\
+9 \\
\pm 0 \\
\pm 0 \\
-2 \\
-6 \\
-16 \\
-12\end{array}$ \\
\hline & Av & rage, & $7 \mathrm{rats}$ & $3+1$ & & & -7 & & -4 \\
\hline
\end{tabular}

* Represents complete occlusion of aorta.

vated kidney transplanted into the neck $(18,25)$; all the afferent nerves being severed, some chemical substance produced in the kidney must be involved. If the hypertension of coarctation is also brought about, as we believe, by a substance derived from the kidney, then we must explain how it is that this material increases peripheral resistance in the upper part of the body but allows a normal or even decreased resistance in the lower part. This need not be a stumbling block, for the all important factor in determining blood flow to a given tissue is the metabolic requirements of the tissue itself. Prinzmetal and Wilson (4) and Pickering (5) have demonstrated that when conditions in the arm tissues are such as to evoke hyperemia, then hyperemia occurs as adequately in hypertensive individuals as it does in normal subjects. In fact, it may be calculated from their data that peripheral resistance in the reactivehyperemic arm of either a hypertensive or a normal subject is only 7 to 12 per cent as great as the resistance in the same subject under control conditions. Since tissue needs for blood may reduce local resistance in generalized hypertension by 90 per cent, it becomes understandable that the resistance in the lower part of the body in coarctation may easily be reduced only as much as the usual 30 to 50 per cent (as compared with the upper part of the body).

The results of Pickering (5) show a similarity between patients with essential or chronic renal hypertension and those with coarctation of the aorta, while Prinzmetal and Wilson (4) found a difference. The latter felt that the hypertension of coarctation was of vasomotor origin, in distinction to the alleged peripheral origin of other varieties of hypertension (including that of acute glomerulonephritis in which Pickering (26) affirms a vasomotor origin). In view of such divergent opinions, and since local conditions (including the metabolites produced locally) act to maintain an adequate local blood flow as long as the cardiac output is normal and the arterial pressure not greatly lowered, it seems unwise to attempt to draw conclusions as to the site of action of the agent causing hypertension in man from data on blood flow in the arm.

Pickering's (5) explanation of the increased peripheral resistance in the upper body in coarctation of the aorta was a supposed failure of growth of that vascular bed, particularly the arteriolovenous anastomoses; such an assumption lacks supporting evidence and is not necessary.

Blumgart et al. (11) found no difference in arteriolar pressure between the arms and legs in coarctation of the aorta. This means only that the fall of pressure gradient occurred proximal to the site of measurement; since the method was an indirect one, the observation is of doubtful significance.

\section{SUMMARY AND CONCLUSIONS}

A consideration of hydrodynamics indicates that the arterial hypertension which is present in the upper part of the body in coarctation of the aorta may not be explained upon the purely mechanical grounds of obstruction to blood flow. In this condition, there is an increased resistance in the smaller vessels (arterioles) which receive blood from the aorta proximal to the stenosis of its isthmus. The cause of this localized increased 
resistance is the same as the cause of the generalized increased resistance in a Goldblatt dog (with partially occluded renal artery); that is, interference with blood supply to the kidneys.

This conclusion is supported by the production of hypertension (cardiac hypertrophy) in rats by partial occlusion of the aorta proximal to one or both renal arteries. With partial occlusion of the aorta between the renal arteries, hypertension occurs only when living renal tissue is present distal to the occlusion; after simultaneous distal nephrectomy, hypertension never occurs even though there exists the same degree of mechanical obstruction to blood flow offered by the stenosis and presence of a collateral bed.

\section{BIBLIOGRAPHY}

1. King, J. T., The blood pressure in stenosis at the isthmus (coarctation) of the aorta; Case reports. Ann. Int. Med., 1937, 10, 1802.

2. Lewis, T., Material relating to coarctation of the aorta of the adult type. Heart, 1933, 16, 205.

3. Barcroft, H., and Samaan, A., The explanation of the increase in systemic flow caused by occluding the descending thoracic aorta. J. Physiol., 1935, $85,47$.

4. Prinzmetal, M., and Wilson, C., The nature of the peripheral resistance in arterial hypertension with special reference to the vasomotor system. J. Clin. Invest., 1936, 15, 63.

5. Pickering, G. W., The peripheral resistance in persistent arterial hypertension. Clin. Sc., 1936, 2, 209.

6. Grollman, A., and Ferrigan, J. P., Jr., Cardiac output; Its related functions in a case of coarctation of the aorta. Arch. Int. Med., 1934, 53, 35.

7. Strayhorn, W. D., Coarctation of the aorta: A case report with observations on the cardiac output during and after pregnancy. In Medical Papers Dedicated to Henry Asbury Christian, Waverly Press, Baltimore, 1936, p. 134.

8. Wezler, K., and Böger, A., Die arterielle Gesamtwiderstand unter verschiedenartigen Sympathicusreizen. Arch. f. exper. Path. u. Pharmakol., 1937, 187,65 .

9. Levy, S. E., and Blalock, A., Fractionation of the output of the heart and of the oxygen consumption of normal unanesthetized dogs. Am. J. Physiol., 1937, 118, 368.

10. Böger, A., and Wezler, K., Die Bestimmung des arteriellen Gesamtwiderstandes am Menschen. Arch. f. exper. Path. u. Pharmakol., 1937, 186, 43.

11. Blumgart, H. L., Lawrence, J. S., and Ernstene, A. C., The dynamics of the circulation in coarctation (stenosis of the isthmus) of the aorta of the adult type. Arch. Int. Med., 1931, 47, 806.

12. Graybiel, A., Allen, A. W., and White, P. D., A histological study of the arterioles of the muscle and skin from the arm and leg in individuals with coarctation of the aorta. J. Clin. Invest., 1935, 14, 52.

13. Goldblatt, H., Lynch, J., Hanzal, R. F., and Summerville, W. W., Studies in experimental hypertension. I. The production of persistent elevation of systolic blood pressure by means of renal ischemia. J. Exper. Med., 1934, 59, 347.

14. Bell, E. T., and Goldblatt, H., Discussion in Am. J. Path., 1936, 12, 761.

15. Rytand, D. A., and Dock, W., Experimental concentric and eccentric cardiac hypertrophy in rats. Arch. Int. Med., 1935, 56, 511.

16. Collins, D. A., Hypertension from constriction of the arteries of denervated kidneys. Am. J. Physiol., 1936, 116, 616.

17. Chanutin, A., and Barksdale, E. E., Experimental renal insufficiency produced by partial nephrectomy. II. Relationship of left ventricular hypertrophy, the width of the cardiac muscle fiber and hypertension in the rat. Arch. Int. Med., 1933, 52, 739.

18. Blalock, A., and Levy, S. E., Studies on the etiology of renal hypertension. Ann. Surg., 1937, 106, 826.

19. Van Slyke, D. D., Rhoads, C. P., Hiller, A., and Alving, A. S., Relationships between urea excretion, renal blood flow, renal oxygen consumption, and diuresis. The mechanism of urea excretion. Am. J. Physiol., 1934, 109, 336.

20. Mason, M. F., Evers, R., and Blalock, A., Renal oxygen utilization of dogs with experimental hypertension. Proc. Soc. Exper. Biol. and Med., 1937, $36,819$.

21. Levy, S. E., Mason, M. F., Harrison, T. R., and Blalock, A., The effects of ureteral occlusion on the blood flow and oxygen consumption of the kidneys of unanesthetized dogs. Surgery, 1937, 1, 238.

22. Dock, W., and Rytand, D. A., Renal blood flow after subtotal nephrectomy. Proc. Soc. Exper. Biol. and Med., 1937, 36, 196.

23. Hartmann, H., Ørskov, S. L., and Rein, H., Die Gefässreaktionen der Niere im Verlaufe allgemeiner Kreislauf-Regulationsvorgange. Arch. f. d. ges. Physiol., 1936-37, 238, 239.

24. Spanner, R., Der Abkürzungskreislauf der menschlichen Niere; Beitrag zur Kenntnis der Leistungszweiteilung ihres Gefässsystems. Klin. Wchnschr., 1937, 16, 1421.

25. Houssay, B. A., and Fasciolo, J. C., in Buenos Aires letter of October 20, 1937. J. A. M. A., 1937, 109, 2002.

26. Pickering, G. W., Observations on the mechanism of arterial hypertension in acute nephritis. Clin. Sc., 1936, 2, 363. 